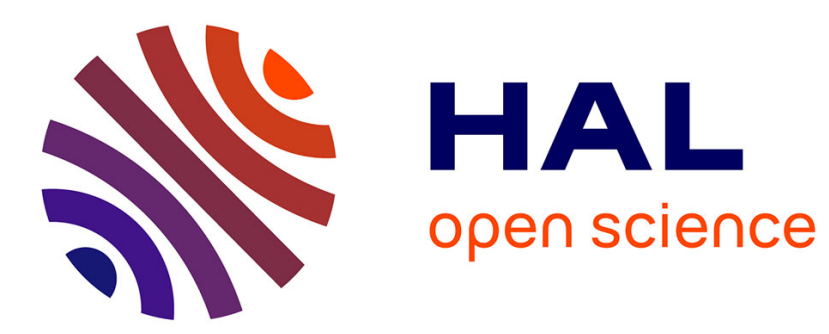

\title{
Hybrid poplar plantations in a floodplain have balanced impacts on farmland and woodland birds
}

\author{
Frédéric Archaux, Hilaire Martin
}

\section{To cite this version:}

Frédéric Archaux, Hilaire Martin. Hybrid poplar plantations in a floodplain have balanced impacts on farmland and woodland birds. Forest Ecology and Management, 2009, 257 (6), pp.1474-1479. 10.1016/j.foreco.2008.12.021 . hal-00455331

\section{HAL Id: hal-00455331 https://hal.science/hal-00455331}

Submitted on 10 Feb 2010

HAL is a multi-disciplinary open access archive for the deposit and dissemination of scientific research documents, whether they are published or not. The documents may come from teaching and research institutions in France or abroad, or from public or private research centers.
L'archive ouverte pluridisciplinaire HAL, est destinée au dépôt et à la diffusion de documents scientifiques de niveau recherche, publiés ou non, émanant des établissements d'enseignement et de recherche français ou étrangers, des laboratoires publics ou privés. 
1 Article paru dans : Forest Ecology and Management, Volume 257, Issue 6, 10 March 2009,

2

3

4

5

6

7

8

9

10

11

12

13

14

15

16

17

18

19

20

21

22
Pages 1474-1479

doi:10.1016/j.foreco.2008.12.021

HYBRID POPLAR PLANTATIONS IN A FLOODPLAIN HAVE BALANCED IMPACTS ON FARMLAND AND WOODLAND BIRDS

Frédéric ARCHAUX

Hilaire MARTIN

Cemagref, Domaine des Barres

F-45290 Nogent sur Vernisson

France

E-mail: frederic.archaux@cemagref.fr

Tel : 00332-38-95-66-79

Fax : 00332-38-95-03-44 


\section{Abstract}

Hybrid poplar plantations are increasing worldwide and are often accused of impoverishing bird communities in surrounding farmland and woodland areas. We conducted 124 bird point counts in a landscape where plantations, semi-natural forests and farmland occupied similar surface areas. As expected, birds occurred at higher densities in forests than in plantations, mostly due to the scarcity of late-successional forest birds in plantations. Contrary to expectations, bird communities were the poorest in farmland dominated areas and the most specialised in areas dominated by young plantations. Indeed, many grassland species, including some of conservation concern in Europe, frequently or almost exclusively used young plantations. However, plantations have probably depleted grassland bird communities by fragmenting open areas, while playing a limited positive role on forest species. Total length of unpaved roads had a positive effect on community specialisation index, while total length of paved roads and mean forest/plantation patch size played no role. Bird density increased with the development of the understory vegetation in mature poplar plantations. We conclude that poplar plantations should be avoided in areas of high conservation value; in other areas, they may increase the overall diversity of bird communities. At the plantation scale, we advocate stopping understory removal as soon as possible and maintaining old trees and hedgerows alongside or within plantations to provide suitable breeding habitats for bird species that may be foraging in the plantations. 


\section{Introduction}

Many fertile floodplains in Europe were occupied by large riparian forests dominated by hardwood tree species (oaks, ash) before the Middle Ages (Petts et al., 1989). Human population growth caused a progressive conversion of a large part of these forests into farmland, while most of the remnants were managed as coppices or coppices with standards for fuel wood production (Steiger et al., 2005). The farming on these lands varied greatly over time and space, and the landscape included pastures, hayfields, various ploughed fields, and more recently maize fields and set-asides. From the XVIIIth century onwards, poplars were often planted at the expense of arable lands and the few forest remnants (Petts et al., 1989). Many factors jointly caused an acceleration of this phenomenon after the 1950s: the embankment of large rivers limited the occurrence and magnitude of floods that poplar plantations are sensitive to, the overproduction of dairy and meat production in Europe caused a strong decrease in cattle numbers, the need for wood fibre increased, poplar plantations (from two-year stems) readily took, and fast-growing, fungus-resistant cultivars became available through hybridization among European, Asian and American Populus species (Schnitzler, 1994). In France, hybrid poplar plantations now represent $1.6 \%$ of the forested area (ca 260,000 ha) and this area is still increasing (+0.8\% between 1988 and 2002, SCEES/Terruti data 2003).

Since 1980, hybrid poplar plantations have been accused of contributing to the decrease in bird populations in floodplains in Western Europe (Zollinger and Genoud, 1979; Schmitz, 1986; Pont, 1987; Mourgaud, 1996; Godreau et al., 1999). However, this seems to be an over-simplification. Indeed, several studies have shown that some uncommon/rare birds may use poplar plantations; for example, the Golden oriole Oriolus oriolus is restricted to mature poplar plantations in Great-Britain (Dagley, 1994). Furthermore, the ecological impact of plantations depends on the habitats they are compared with: Hanowski et al. (1997) in 
North America showed that the number of breeding birds was higher in poplar plantations than in the row crops the plantations were replacing but less than in surrounding forest/shrub habitat. Finally, extensively-managed plantations may be less unfavourable to breeding birds than intensively-managed ones (Pont, 1987; Godreau, 1998).

We believe further studies are needed to confirm some of these results and better understand the impact of hybrid poplar plantations on bird communities. In particular, the previous studies rarely used a landscape perspective (but see Hanowski et al., 1997; Godreau, 1998) and yet, many birds need a mosaic of adjacent habitats to breed and forage (e.g. Virkkala et al., 2004). Furthermore, the poplar plantations studied so far have usually been isolated within a farmland matrix and have always represented a minor proportion of the landscape (e.g. at most $12 \%$ in area, Godreau, 1998) and yet isolation of forest fragments is well-known for causing deleterious effects on bird communities, irrespective of tree species (Blake and Karr, 1987; Hinsley et al., 1995). More connected poplar plantations may host more woodland species, as suggested by Godreau (1998).

In this study, we focused on a floodplain area in northern France where semi-natural forests, poplar plantations and farmland represented equivalent proportions in the landscape. Within this landscape, we assessed how bird communities responded to habitat composition at three different spatial scales (100, 250 and 500m-radius circles). More specifically, our main working hypotheses were:

- bird densities decrease with an increasing proportion of poplar plantations in the surroundings,

- the greater the area planted with hybrid poplar, the less specialised the bird communities,

- the presence of forest birds depends mainly on semi-natural forest areas but also, to a smaller extent, on mature poplar plantations, 
- bird densities vary with the fragmentation of habitats,

- bird densities in plantations increase with understory vegetation cover due to larger areas suitable for breeding/foraging and/or to a higher number of potential niches.

\section{Methods}

\subsection{Study area}

The 6950-ha study area is located between Romilly-sur-Seine and Méry-sur-Seine (France, Aube department, ca 100-120m asl), along $20 \mathrm{~km}$ of the Seine River on deep, chalky soils corresponding to modern alluvial deposits. The climate is Atlantic with continental influences (mean annual temperature ca $10^{\circ} \mathrm{C}$ with $630-700 \mathrm{~mm}$ annual rainfall). Poplar plantations represent $27 \%$ of the area due to the unusual width $(2-3 \mathrm{~km})$ of the floodplain (nearby confluence of the Seine with the Aube River). Other land uses found in the floodplain were farmland and open areas (36\%), forests (22\% including abandoned poplar plantations), urban areas $(11 \%)$ and aquatic areas (4\%). The poplar plantations did not differ from that of forests in terms of median size (Wilcoxon rank-sum test, $\mathrm{W}=151758, \mathrm{P}=0.52$ ) but other areas (farmland, other open, urban and aquatic areas) were significantly larger than poplar plantations $(\mathrm{W}=226243, \mathrm{P}=0.001)$ and forests $(\mathrm{W}=155897, \mathrm{P}=0.02)($ Table 1$)$. The study area extended slightly beyond the floodplain bottom onto the intensive row crop fields of the plateau, so as to allow us to calculate habitat areas surrounding bird sampling points up to $500 \mathrm{~m}$. Crop fields are also found within the plain (including maize fields), along with setasides and, to a far lesser extent, hay pastures. The nearest large forest (the "Traconne") state forest that may be a source of forest birds is about $10 \mathrm{~km}$ from the study area. As hedgerows are also scarce on the plateau, bird exchanges between forested areas in the valley and the 
plateau are probably limited. At a larger scale (Aube and Seine floodplains sensu the French

121 National Inventory: 34,025 ha), hardwood forests decreased by 53\% between 1974 and 1994, representing only $5.5 \%$ of the total area in 1994 (ca 1,660ha) versus 3,740ha for poplar plantations (French Forest Inventory data, 1994).

The study area was first mapped from colour aerial photographs taken in 2001 and 2004 (NGI data). We separated unpaved and paved roads and identified nine major habitats: (1) very young VYP, (2) young YP and (3) mature MP poplar plantations; (4) young YF and (5) old OF hardwood forests; (6) farmland Farm (cropland and grassland combined); (7) urban areas; (8) aquatic areas (rivers, ponds, lakes) and (9) other open habitats. We attributed one of these habitat classes to the 1,592 polygons that were individualised from aerial photos;

130 then, in the field, we checked the correctness of this attribution. In the field, poplar stands were attributed to the very young class when the mean diameter at breast height (dbh) was less than $20 \mathrm{~cm}$, to the young class when the dbh was between 20 and $30 \mathrm{~cm}$, and to the mature class when above $30 \mathrm{~cm}$ (i.e. when the canopy closes). In the area, poplars are cut when about 20 years old. Mean distance between poplars in plantations is almost invariably $7 \mathrm{~m}$ in the area (occasionally 6 or $8 \mathrm{~m}$ ). Plantations are ploughed, and sometimes fertilised, at plantation; the clones most often used are Populus x interamericana "Beaupré" and P. x canadensis "I214". The understory vegetation is mechanically and/or chemically removed during the first years after planting. This control may be either continued more or less regularly (intensive management) or ceased (extensive). In the case of intensive management, the vegetation

140 understory is limited to sedges and grasses (including Nettle Urtica dioca). In extensively 141 managed plantations, a shrubby layer develops with Blackthorn Prunus spinosa, Common

142 Elder Sambucus nigra, Willow Salix sp, and Blue Bramble Rubus caesius. All the young 143 forest stands (YF) actually originated from former poplar plantations cleared in December 1441999 after the Lothar windstorm (ca 30\% of the plantations in the study area were cleared) 
and never replanted: these stands could be considered either as very extensive young poplar

146 plantations (due to the presence of naturally resprouting poplars) or young semi-natural

147 forests (due to the rapid recolonisation by ash and other shrubs). Old forest stands (OF)

148 included a variety of forest types, from most to least common: (1) coppiced Hazel Corylus

149 avellana with standards of Pedunculate Oak Quercus robur and Ash Fraxinus excelsior, (2)

150 abandoned over-mature poplar plantations overgrown by Ash, (3) spontaneous riparian forests

151 (including the previously mentioned species, as well as Alder Alnus glutinosa, Sycomore

152 Maple Acer pseudoplatanus, Smooth-leaved Elm Ulmus minor and various willow species

153 Salix sp. along river beds) and (4) old Ash/Hazel coppices.

\subsection{Bird point counts}

124 bird point counts were located throughout the study area, based on a quasisystematic grid design (ca 400m between points). We located the majority of the points along paths for efficiency and discretion (a few were carried out along roads with limited traffic at

160 the time of the counts). Each point was visited twice (two 5-min counts), first between April

16116 and 27 (between 6:30 and 9:43 am), and second between the May 30 and June 8, 2007 (between 5:42 and 9:32 am). All counts were carried out under good weather conditions (no 163 wind, no rain).

164 During the count, the observer (FA) used aerial photographs centred on the points to 165 localise all singing (the great majority) or moving/flying (a minority) birds. The fact that the

166 landscape was very fragmented helped to locate the birds. As for the territory mapping

167 method, the observer estimated whether the birds recorded during the second visit had already

168 been detected during the first visit (according to the spatial proximity among the contacts). A 169 total of 2,482 individual birds (62 species) were recorded and incorporated in the GIS. Total 
cover for the $1-4 \mathrm{~m}$ and $4-8 \mathrm{~m}$ vegetation layers was visually estimated (and classified in $5 \%$ increments above a minimum $5 \%$ total cover). The mean poplar dbh was measured in poplar plantations immediately surrounding the points (but not in more distant plantations).

\subsection{Data analyses}

To test our working hypotheses, for each point we estimated the bird density, the mean specialisation and preference for mature forests of the bird community. Only birds recorded within $100 \mathrm{~m}$ of the observer were kept ( $\mathrm{N}=1138,47$ species). To adjust raw count data for imperfect detection, we treated the two visits as two replicate counts and calculated the total number of individuals A (observed abundance) and the number of individuals recorded at only one visit $\left(n_{1}\right)$. We calculated the Jackknife 1 estimator $\left(\right.$ Jack $\left.1=A+n_{1} / 2\right)$ and its standard deviation ( $S D=1 / 2 \sqrt{ }\left(3 n_{1}\right)$ ) for each point as an estimate of the total number of birds (all species) present within $100 \mathrm{~m}$. This estimator assumes heterogeneity of detection among species (Burnham and Overton, 1979), a classical phenomenon in bird communities

(Boulinier et al., 1998). Density (number of pairs.ha ${ }^{-1}$ ) was then estimated as Jack $1 / \pi$ (the area $100 \mathrm{~m}$ around the point, in ha). In models, we used the inverse of the variance of the density estimate to weight observations: observations for which density was known with lesser precision were logically given smaller weight.

We calculated the community specialisation index (CSI), a measure of the mean specialisation of the bird community (Julliard et al., 2003), using data from the specialisation index of 105 common birds by Devictor et al. (2007). The CSI index is known to correlate well with the level of landscape fragmentation and disturbance (Devictor et al., 2007). The higher the CSI, the more specialised the bird community. We followed the same rationale to define the community preference for mature forests (CPMF). Muller (1985) provided the 
mean age of the forest stands for 40 common European bird species where these species were

196 observed in French oak regular high forest stands; stand age varied from 10 years for the early-successional Willow Warbler Phylloscopus trochilus to 147 years for the latesuccessional Short-toed Treecreeper Certhia brachydactyla. CPMF was calculated as the mean stand age over all species recorded within $100 \mathrm{~m}$. The greater the CPMF, the more typical the bird community to mature forests. In analyses, we kept only points for which CSI and CPMF indices could be calculated from at least five species and we weighted the observations in models using the inverse of the variance of the index estimate (as for species richness).

Using the GIS, we extracted the area covered by the nine pre-defined habitats within 100,250 and $500 \mathrm{~m}$ of the point. We also recorded the cumulated length of (1) unpaved roads and (2) paved roads within the same radii. Finally, we calculated the mean patch size 100, 250 or 500m around the point (MPS) for plantations and forest patches. We modelled the impact of these explanatory variables on the different community indices defined above using spatially-explicit GAM models. A generalized additive model (GAM) is a generalized linear model (GLM) in which spatial autocorrelation is modelled using a non-parametric, smooth

211 function of the geographical coordinates of the study points (using the gam function from $\mathrm{R}$ 212 library mgcv). To limit spurious effects of non-focal habitats (aquatic, gardens, urban, open 213 habitats other than farmland), we excluded from our analyses 20 points where these habitats 214 represented more than $5 \%$ of the area within $100 \mathrm{~m}$ around the point. The final data set 215 contained 104 points for species richness, 85 for the CSI and 79 for the CPMF. To identify 216 the spatial scale that could explain the largest part of the total variance in the community 217 indices, we built models including all nine selected variables (farmed area, very young 218 plantation area, young plantation area, mature plantation area, young forest area, old forest area, mean patch size of plantations and forests, cumulative length of paths, cumulative length 
of roads) calculated either on 100, 250 or 500m around the point. Then, we compared the relative merits of the three models with AIC (the lower the AIC value, the better). To further investigate how the community indices varied among the six habitat area variables, we used the model with the lowest AIC value in the preceding step of the analysis and we progressively aggregated habitat area variables whose model coefficients were roughly similar until the AIC of the resulting simpler model did not decrease any further: this step of grouping habitat variables revealed which (groups of) habitats had similar and distinct impacts on the bird communities. The significance of the MPS and length of paths and roads variables was directly tested from an ANOVA (using the ANOVA function in R). It was difficult to reliably assess the impact of the understory vegetation in plantations on birds. Indeed, many plantations were small, leading to potentially confounding edge effects. Furthermore, the observer rarely stood within the plantations during the counts, so that only part of the larger plantations may have been effectively "sampled" (a positive aspect of this sampling design is nonetheless that singing birds were less disturbed). We addressed this issue by restricting our analyses to birds recorded within $100 \mathrm{~m}$ of the observer, in mature plantations (mean dbh over $30 \mathrm{~cm}$ ) covering at least 1 ha within a $100 \mathrm{~m}$ radius of the point (ca $>30 \%$ of the circle area). We further excluded all narrow plantations to limit edge effects, finally retaining a list of 28 patches of mature plantations. We then estimated a density per patch by dividing the number of birds recorded in a given patch (all species confounded, corrected for imperfect detection using the Jackknife 1) by patch size. We built simple linear

240 models on unadjusted bird density with the $1-4 \mathrm{~m}$ and $4-8 \mathrm{~m}$ cover indices as explanatory 241 variables. Unadjusted bird density is given in Table 3 for the 20 most common bird species in 242 the six main habitats considered in this study.

\section{Results}


Mean bird density (Jackknife1) over the 104 point counts was estimated at ca $3.8 \pm 1.5$

247 pairs.ha ${ }^{-1}$ (assuming a singing male corresponds to a breeding pair). Little spatial

248 autocorrelation was found as the effect of the spatial smoother was never significant. Bird

249 density was correlated to neither CSI nor CPMF, but the latter two variables were highly

250 negatively correlated (Pearson's $\mathrm{r}=-0.55, \mathrm{t}=-5.7 \mathrm{df}=77, \mathrm{P}<0.001$ ). For the three indices,

251 the model including explanatory variables defined locally (i.e. 100m around the point) had a

252 significantly lower AIC value than models including variables defined at larger scales (250 or

$253500 \mathrm{~m}$ ) (Table 2). Models explained a reasonable part of the variance for CPMF but a more

254 limited part for CSI and bird density, reflecting either measurement error or less determinism

255 in these variables (Table 2).

256 Bird density primarily decreased with farmland area and was highest in forests (Table

257 2). Interestingly, several habitats contributed to the CSI and CPMF but at different levels: CSI

258 increased primarily with the area of very young and young poplar plantations and secondarily

259 with the area of farmland. Similarly, CPMF was mostly related to the area of old forests but

260 the negative impact of the main other habitats gradually decreased with the structural

261 similarity of the habitat to old forest (this similarity increasing from (1) very young

262 plantations, (2) farmland and young plantations, (2) young forest to (3) mature plantations).

263 None of the three indices was significantly related either to the mean patch size of

264 plantations and woodlands, or to the cumulative length of roads. Only the mean level of

265 specialisation of the species increased with the length of footpaths.

266 Variation in bird density between plantations increased with the increase in the

267 understory cover. Nonetheless, log-transformed bird density (to limit heteroscedasticity)

268 increased more or less linearly with the understory cover up to $30 \%$ (Pearson's $r=0.62$, 
$\mathrm{t}=3.88, \mathrm{df}=24, \mathrm{P}<0.001$ ) and then seemed to stabilise (Fig. 1). On the contrary, bird density was unrelated to the overstory cover (Pearson's $r=-0.22, \mathrm{t}=-1.1, \mathrm{df}=26, \mathrm{P}=0.17$, Fig. 2).

\section{Discussion}

Our results show that the impacts of poplar plantations on bird communities are more complex than it is usually claimed: birds in poplar plantations did occur in lower densities than in semi-natural forest stands (whatever stand age) but in higher densities than in farmed in old forest stands; yet a truncated succession in bird communities occurred along the poplar rotation, the composition of bird communities in mature plantations being somewhat intermediate between young and old forest stands. Finally, contrary to what is generally thought, the most specialised bird communities were found in the very young and young poplar plantations, whereas mature plantations and forests hosted the least-specialised bird communities.

\subsection{Plantations versus farmland}

Bird communities were also found to be poorer in intensively-managed farmland than in short-rotation hybrid poplar plantations in North America (Hanowski et al., 1997). Bird populations in our study valley are probably also suffering from the intensive management of the farmland. Obviously, the set-asides and the too few and too artificial grasslands play a

291 reduced protective role for grassland birds in the area. In addition, plantations may have exacerbated the decline in grassland species by fragmenting the grassland areas. Indeed,

293 Godreau et al. (1999) showed that many grassland species were very sensitive to the 
fragmentation of open habitats along the Saône River, a few hundred km south of our study site. The relatively large areas planted with poplars in our site probably explain why many of the specialist grassland species that could normally breed in our floodplain were either never recorded (Quail Coturnix coturnix, Black-tailed Godwit Limosa limosa, Curlew Numenius torquata, Meadow Pipit Anthus pratensis, Whinchat Saxicola rubetra and Yellow Wagtail Motacilla flava) or very rarely recorded (Lapwing Vanellus vanellus, Skylark Alauda arvensis, Corn bunting Miliaria calandra, Pied wagtail Motacilla alba and finches Carduelis $s p)$. Yet, some of these species were regularly observed in the immediate neighbourhood of the study area (the Skylark, Corn Bunting and Yellow Wagtail on the purely agricultural plateau, finches in urban areas), supporting the hypothesis that the valley is repulsive to many grassland birds. Finally, plantations probably favoured the Carrion Crow Corvus corone which appreciates the mosaic of interconnected farmland and woodland patches; this species is known to heavily predate on the eggs of grassland ground nesters (Andren, 1992).

Although poplar plantations at the landscape scale may contribute to the near absence of many grassland species, several ground- and shrub-nesters usually found in farmland along hedgerows were commonly recorded in very young and young plantations. The same pattern was found along the nearby Saône River (Godreau et al., 1999). Interestingly, Yellowhammer Emberiza citrinella was recorded as frequently in very young poplar plantations as in farmland. Other species found in very young and young plantations included Melodious Warbler Hippolais polyglotta, Whitethroat Sylvia communis, Grasshopper Warbler Locustella naevia and, more marginally, Red-backed Shrike Lanius collurio. These species are considered to be habitat specialists (Devictor et al., 2007), a fact that probably explains why the most specialised bird communities were found in areas dominated by very young and young plantations. 
The lower bird density in plantations compared to semi-natural forests has repeatedly

been found in Western Europe and North America (Schmitz, 1986; Hanowski et al., 1997;

Godreau, 1998; Twedt et al., 1999). This pattern is mostly due to the scarcity in plantations,

even mature, of forest species that prefer old trees with a dense foliage to forage or breed such as the Woodpigeon Columba palumbus, Blue Tit Cyanistes caeruleus, Nuthatch Sitta europaea, Short-toed Treecreeper and Chaffinch Fringilla coelebs (Table 3). Although cavity-nesters were logically more frequent in forests than in plantations, mature poplar plantations in our study were regularly used by the Great-spotted Woodpecker Dendrocopos major, the Great Tit Parus major (breeding in abandoned cavities of the Great-spotted

330 Woodpecker) and the Willow Tit Poecile montanus. Dead poplars may be suitable to this species that needs decaying softwood trees to dig its own cavities. that of the young forests: species like Stock Dove Streptopelia turtur, Winter Wren Troglodytes troglodytes, Nightingale Luscinia megarhynchos, Melodious Warbler, Blackcap Sylvia atricapilla, Garden Warbler Sylvia borin and Starling Sturnus vulgaris preferred young forests to young plantations, probably in response to the higher structural and compositional diversity of the shrub layer (the starling was probably also favoured by the presence of old poplar snags in many young forest patches). Conversely, the Tree Pipit Anthus trivialis and

339 Grasshopper Warbler were more frequently found in young plantations: they respectively

340 forage on or close to the ground, in dense herbaceous vegetation; these two species rapidly 341 colonise plantations after planting and desert them a few years later, as the canopy closes. More surprisingly, the level of specialised bird communities was lowest in the areas dominated by forests (at a level similar to that of mature poplar plantations). Actually, as for 
344 farmland, among the forest specialist species potentially present in floodplain forests

345 (Godreau et al., 1999), some were never recorded (Middle-spotted Woodpecker Dendrocopos

346 medius, Wood Warbler Phylloscopus sibilatrix) or very rarely (Lesser-spotter Woodpecker

347 Dendrocopos minor, Spotted Flycatcher Muscicapa striata, Hawfinch Coccothraustes

348 coccothraustes). In our study, the semi-natural forest fragments are probably too small and

349 isolated to allow these area-sensitive birds to maintain viable populations.

350 Several authors argued that the development of understory in extensively-managed

351 poplar plantations is favourable to small birds (Schmitz, 1986; Godreau, 1998). We did in fact

352 observe that bird density increased with the vegetation cover between 1 and $4 \mathrm{~m}$ (though

353 possibly not linearly), but this was not the case above $4 \mathrm{~m}$. Our sample size was too small to

354 statistically assess whether the higher bird density in extensively-managed plantations was

355 primarily caused by a greater number of species or simply by a higher abundance of the same

356 set of species. In the study by Godreau (1998), the number of species more frequently

357 recorded in intensively-managed plantations did not differ statistically from the number of

358 species more frequently found in extensively-managed plantations (16 versus 19, binomial

359 test, $\mathrm{P}=0.74)$. Thus, extensive management of the plantations probably improves the overall

360 quality of the mature plantations more than it provides new niches benefiting new species; as

361 a result, it probably mainly favours the species already able to cope with the initial intensive

362 management of poplar plantations. This hypothesis may also hold in North America since

363 Christian et al. (1996) also conclude that (aspen) stand thinning has a weakly positive and

364 transitory effect on species abundances but none on the number of breeding species. 

plantations increased with the size of the plantation. We found little convincing evidence of any effect of habitat fragmentation, except for a positive impact on the length of unpaved roads on the mean community specialisation. The vegetation along unpaved roads is likely to provide food resources that are otherwise limited in fields for several specialist birds, especially seed-eaters such as yellowhammer and stock dove. The fact that the mean size of 374 forest and plantation patches (MPS) moderately varied among points (MPS within 100-m radius disks exceeded 2 ha for only eight of the 104 points) probably explains why we failed to find an effect on bird communities. Similarly, paved roads were present within $100 \mathrm{~m}$ of the points in only 14 points (by comparison, 87 points included paths within 100m).

\subsection{Implications for bird conservation in floodplains}

This study gives a balanced view of the impact of poplar plantations on common birds in floodplains. On one hand, plantations do not provide refuge habitats for the most specialised grassland and woodland birds. On the other hand, several woodland birds use 384 mature plantations (although often at lower densities than in semi-natural forests). Thus, the conversion of intensive crop fields by plantations may be beneficial to some open-land and woodland birds (at different ages of the plantations). On one hand, in areas of high conservation value, they probably contribute to the loss of the most area-sensitive birds in

388 floodplains by causing the loss and fragmentation of grassland and woodland. On the other 389 hand, in already fragmented and intensively-managed farming areas such as our study area, 390 many grassland birds, including some that are currently declining all over Europe, use young 391 plantations to breed (although it remains to be demonstrated that young plantations are not 392 also demographic sinks). 
At the scale of the plantation, extensive management has a positive impact on bird

394 density. This means that the removal of understory should stop as soon as the understory no

395 longer threatens the growth of poplars. In addition, plantations seem to lack breeding places

396 for many species, although plantations may represent valuable foraging habitats. For instance,

397 the presence of the great tit in mature plantations probably indicates that other cavity-nesters

398 would breed in plantations if sufficient cavities would be available: thus, the retention of large

399 old/decaying poplars, ashes or oaks within or along the plantation would probably favour

400 cavity-nesters. Those trees with a dense crown would also represent breeding sites safer than

401 poplars for species nesting in tree crown. Alternatively, nest-boxes may be installed in

402 plantations as suggested by Twedt and Henne-Kerr (2001). Similarly, hedgerows may be

403 installed between plantations or within large plantations to the benefit of shrub bird species.

404 The supplementary cost related to the retention of old trees and hedgerows may be partly

405

406

407

compensated by a better regulation of poplar defoliating insect populations since these measures would be mostly beneficial to insectivorous birds.

\section{Acknowledgments}

We are grateful to R. Chevalier and E. Dauffy-Richard, B. Faivre and V. Godreau for discussion on bird sampling and data analysis, and to Vicky Moore for improving the clarity of manuscript. This study was funded by a grant from the GIP ECOFOR and the Ministries in charge of the Ecology and the Forest.

\section{References}

Andren, H., 1992. Corvid density and nest predation in relation to forest fragmentation: a landscape perspective. Ecology 73, 794-804. 
Blake, J., Karr, J., 1987. Breeding birds of isolated woodlots: area and habitat relationships. Ecology 68, 1724-1734.

Boulinier, T., Nichols, J.D., Sauer, J.R., Hines, J.E., Pollock, K.H., 1998. Estimating species richness: the importance of heterogeneity in species detectability. Ecology 79, 1018-

Burnham, K.P., Overton, W.S., 1979. Robust estimation of population size when capture probabilities vary among animals. Ecology 60, 927-936.

Christian, D.P., Hanowski, J.M., Reuvers House, M., Niemi, G.J., Blake, J.G., Berguson, W.E., 1996. Effects of mechanical strip thinning of aspen on small mammals and breeding birds in northern Minnesota, U.S.A. Can. J. For. Res. 26, 1284-1294.

Dagley, J., 1994. Golden orioles in East Anglia and their conservation. Brit. Birds 87, 205219.

Devictor, V., Julliard, R., Clavel, A., Jiguet, F., Lee, J., Couvet, D., 2007. Functional biotic homogenization of bird communities in disturbed landscapes. Glob. Ecol. Biogeogr. 17, 252-261.

Godreau, V., Bornette, G., Frochot, B., Amoros, C., Castella, E., Oertli, B., Chambaud, F., Oberti, D., Craney, E., 1999. Biodiversity in the floodplain of Saône: a global approach. Biodivers. Conserv. 8, 839-864.

Godreau, V., 1998. Impact des changements d'occupation des sols et de la populiculture sur

Hanowski, J.M., Niemi, G.J., Christian, D.C., 1997. Influence of within-plantation heterogeneity and surrounding landscape composition on avian communities in hybrid poplar plantations. Conserv. Biol. 11, 936-944. 
Hinsley, S.A., Bellamy, P.E., Newton, I., Sparks, T.H., 1995. Habitat and landscape factor influencing the presence of individual breeding bird species in woodland fragments. J. Avian Biol. 26, 94-104.

Julliard, R., Jiguet, F., Couvet, D., 2003. Common birds facing global changes: what makes a species at risk? Glob. Change Biol. 10, 148-154.

Mourgaud, G., 1996. Etude comparative des passereaux nicheurs en prairie alluviale et en peupleraie dans les Basses Vallées Angevines. Crex 1, 25-31.

Muller, Y., 1985. L'avifaune forestière nicheuse des Vosges du Nord. Sa place dans le contexte médio-européen. Dissertation, Université de Bourgogne, France.

Petts, G.E., Möller, H., Roux, A.L. (eds), 1989. Historical change of large alluvial rivers: Western Europe. John Wiley and Sons, Chichester.

Pont, B. 1987. Comparaison de l'avifaune nicheuse d'une ripisylve et de peupleraies de la moyenne vallée du Rhône (île de la Platière). Bièvre 9, 9-16.

Schmitz, L., 1986. Avifaunes nicheuse et hivernante des peupleraies de Hesbaye occidentale. Aves 23, 81-120.

Schnitzler, A., 1994. Conservation of biodiversity in alluvial hardwood forests of the temperate zone: the example of the Rhine Valley. For. Ecol. Manage. 68, 385-398.

Steiger, J., Tabacchi, E., Dufour, S., Corenblit, D., Peiry, J.-L., 2005. Hydrogeomorphic processes affecting riparian habitat within alluvila channel-floodplain river systems: a review for the temperate zone. River Res. Applic. 21, 719-737.

Twedt, D.J., Wilson, R.R., Henne-Kerr, J.L., Hamilton, R.B., 1999. Impact of forest type and management strategy on avian densities in the Mississippi Alluvial Valley, USA. For. Ecol. Manage. 123, 261-274.

Twedt, D.J., Henne-Kerr, J.L., 2001. Artificial cavities enhance breeding bird densities in managed cottonwood forests. Wildl. Soc. Bull. 29, 680-687. 
467 Virkkala, R., Luoto, M., Rainio, K., 2004. Effects of landscape composition on farmland and 468 red-listed birds in boreal agricultural-forest mosaics. Ecography 27, 273-284.

469 Zollinger, J.L., Genoud, M., 1979. Etude comparée de l'avifaune de ripisylves et de 470 populicultures aux Grangettes (Vaud). Nos Oiseaux 35, 45-64. 
Table 1

472 Impact of landscape variables on bird assemblages (BD bird density, CPMF community

473 preference for mature forests, CSI community specialisation index $)^{1}$. a) AIC values of the

474 three alternative models based on the same set of variables but defined at three different

475 spatial scale (100, 250 and 500m around the point)); in bold the model with the lower AIC

476 before aggregating habitat area variables (Farm to OF variables); the \% deviance of this

477 model in provided in b); in superscript AIC of the best model after aggregating the habitat

478 area variables. c) Fitted coefficients and standard errors of the explanatory variables

479 corresponding to the model in bold in a) (removing the intercept) and in superscript (a-d)

480 variables whose aggregation improves model AIC (the AIC of the corresponding model is the

481 value in superscript in a)). For MPS, Paths, Roads and the smoother: * $\mathrm{P}<0.05$, italics $\mathrm{P}<0.1$.

\begin{tabular}{|c|c|c|c|c|}
\hline & Variables & $\mathrm{BD}$ & CPMF & CSI \\
\hline a) & AIC (100/250/500) & $\mathbf{6 1 7}^{612} / 619 / 632$ & $\mathbf{5 8 7}^{584} / 599 / 610$ & $-\mathbf{1 0 8}^{-113} /-85 /-82$ \\
\hline b) & $\%$ Dev & 36.8 & 67.9 & 39.1 \\
\hline \multirow[t]{10}{*}{ c) } & Farm & $1.2 \pm 0.6^{\mathrm{a}}$ & $10.5 \pm 2.5^{\mathrm{a}}$ & $-0.27 \pm 0.02^{\mathrm{a}}$ \\
\hline & VYP & $3 \pm 0.7^{b}$ & $6.5 \pm 1.2^{b}$ & $-0.20 \pm 0.03^{b}$ \\
\hline & YP & $3.1 \pm 0.7^{b}$ & $11.2 \pm 2.1^{\mathrm{a}}$ & $-0.24 \pm 0.03^{b}$ \\
\hline & MP & $3.6 \pm 0.5^{b}$ & $15.2 \pm 1.3^{\mathrm{c}}$ & $-0.33 \pm 0.02^{c}$ \\
\hline & YF & $4.5 \pm 1^{\mathrm{c}}$ & $12.4 \pm 1.9^{\mathrm{a}}$ & $-0.34 \pm 0.03^{\mathrm{c}}$ \\
\hline & $\mathrm{OF}$ & $5.1 \pm 0.7^{\mathrm{c}}$ & $22.1 \pm 1.8^{\mathrm{d}}$ & $-0.34 \pm 0.02^{c}$ \\
\hline & MPS & $-1.0 \pm 0.8$ & $-4.5 \pm 2.3$ & $0.03 \pm 0.02$ \\
\hline & Paths & $0.3 \pm 0.5$ & $-1.5 \pm 1.2$ & $0.03 \pm 0.01 *$ \\
\hline & Roads & $0.6 \pm 0.4$ & $1.7 \pm 0.9$ & $0.0 \pm 0.01$ \\
\hline & Smooth df & 10.8 & 5.8 & 3.2 \\
\hline
\end{tabular}


$482{ }^{1}$ Farm farmland, VYP/YP/MP very young/young/mature poplar plantations, YF/OF young/old forests, MPS 483 mean patch size of plantations and forests (all in ha), Paths/Roads cumulated length of paths or roads (km);.

484 Smooth df: estimated degree of freedom of the spatial smoother. 
Table 2

486 Bird density (number of singers/10ha) of the 20 most common species calculated from the 487124 point counts of the study depending on the habitat where the individual was recorded 488 (\#Ind: total number of individuals recorded within 100m around the points, see also Table 2 489 legend).

\begin{tabular}{|c|c|c|c|c|c|c|c|}
\hline Species & \#Ind & Farm & VYP & YP & MP & $\mathrm{YF}$ & $\mathrm{OF}$ \\
\hline Columba palumbus & 39 & 0 & 0 & 0.3 & 1.1 & 0.9 & 2.4 \\
\hline Streptopelia turtur & 22 & 0.2 & 0 & 0 & 0.6 & 1.8 & 0.9 \\
\hline Dendrocopos major & 14 & 0 & 0 & 0.6 & 0.8 & 0 & 0.3 \\
\hline Anthus trivialis & 27 & 0.4 & 2.2 & 0.9 & 0.2 & 1.2 & 0.5 \\
\hline Troglodytes troglodytes & 73 & 0 & 0.6 & 0.9 & 2.7 & 1.5 & 3.4 \\
\hline Erithacus rubecula & 132 & 0 & 0.6 & 1.1 & 4.8 & 3.1 & 6.5 \\
\hline Luscinia megarhynchos & 42 & 0 & 0.4 & 2.0 & 1.2 & 2.5 & 1.2 \\
\hline Turdus merula & 50 & 0 & 0.4 & 1.4 & 1.5 & 1.8 & 2.2 \\
\hline Turdus philomelos & 18 & 0 & 0.2 & 0 & 0.6 & 0 & 1.1 \\
\hline Locustella naevia & 31 & 0.4 & 2.8 & 1.4 & 0.4 & 1.5 & 0 \\
\hline Hippolais polyglotta & 17 & 0.2 & 0.8 & 0.3 & 0.4 & 1.5 & 0.2 \\
\hline Sylvia communis & 46 & 0.4 & 3.2 & 1.4 & 1.0 & 2.8 & 0.3 \\
\hline Sylvia borin & 27 & 0 & 0.2 & 0.9 & 1.0 & 1.5 & 0.8 \\
\hline Sylvia atricapilla & 190 & 0.4 & 1.4 & 5.7 & 7.1 & 7.1 & 6.2 \\
\hline Phylloscopus collybita & 117 & 0 & 2.0 & 4.0 & 5.1 & 2.8 & 2.8 \\
\hline Cyanistes caeruleus & 44 & 0 & 0 & 0.9 & 1.1 & 1.5 & 2.6 \\
\hline Parus major & 49 & 0 & 0 & 0.6 & 2.1 & 0.3 & 2.3 \\
\hline Certhia brachydactyla & 19 & 0 & 0 & 0 & 0.4 & 0.6 & 1.3 \\
\hline Sturnus vulgaris & 16 & 0.4 & 0 & 0.3 & 0.4 & 0.9 & 0.5 \\
\hline
\end{tabular}


$\begin{array}{lllll}0.2 & 1.1 & 1.9 & 1.5 & 4.9\end{array}$

490 